\title{
Yaratıcı Dramanın Okula Yabancılaşma Yaşayan İlköğretim 5. Sınıf Öğren- cileri Üzerindeki Etkisinin Çocukların Tiyatrosu Yoluyla İncelenmesi
}

\author{
Özlem YILMAZ*
}

\author{
Serap ANTEPLI**
}

\begin{abstract}
Özet
Bu çalışmanın amacı, yaratıcı drama yönteminin okula yabancılaşma yaşayan ilköğretim 5. sinıföğrencilerinin yabancllaşma düzeyleri üzerindeki etkisinin çocukların tiyatrosu yoluyla incelenmesidir. Çalışma, 2008-2009 eğitim-ögretim yılında Ankara ili Çubuk ilçesindeki resmî bir ilkögrretim okulunda yapılmıştır. Çalışma, 5. sınıf ögrencilerine uygulanan "Öğrenci Yabancilaşma Ölçeği” (ÖYÖ) sonucunda, yabanctlaşma puanı en yüksek çıkan 6’sı erkek, 7'si kız toplam 13 ögrenci ile yürütülmüşsür. Çallşmada, öğrencilerle toplam 38 saatlik on dört oturum yapılmıştır. Bu oturumların ardından yapılan atölye çalışmalarından yola çıklarak bir tiyatro gösterisi hazırlanmasına karar verilmiştir. Bu gösterinin sahneleme aşaması için 24 saatlik ön hazırlık, sahneleme öncesi için de iki kez genel prova çalıșması yapılmuștır. Gösterinin hazırlanmasında literatürde "Çocukların Tiyatrosu" olarak geçen ve tamamen yaratıcı drama ile gerçekleşen bir yöntem kullanılmıştır. Atölye çalışmalarındaki canlandırmalar doğrultusunda yapılan sahneleme çalışmaları sonucunda, davetiyesi, metni, ad, dekoru ve kostümü tamamen çocuklara ait "Hayaller ve Gerçekler Okulu”" isimli tiyatro gösterisi sergilenmiştir. Çalışmaların başında 13 öğrenciye ön test olarak uygulanan ÖYÖ, çalışma sonunda son test olarak tekrar uygulanmıştır. Buna göre (istatistiksel olarak) ögrencilerin okula yabancılaşma ön test-son test puanları arasindaki farkın manidar olup olmadĭ̆ ilişsili örneklem için t-testi analizi ile kontrol edilmiştir. Analizde manidarlı düzeyi.05 olarak alınmıştır. Şonuç olarak veri toplama araçlarından elde edilen bulgulara göre yaratıcı drama yöntemi ile katılımcıların yabancılaşma puanlarının manidar düzeyde farklılaştı̆̆ ve son test puanlarının ön test puanlarından daha düşük olduğu görülmüştür.
\end{abstract}

Anahtar sözcükler: Yaratıcı Drama, Çocukların Tiyatrosu, Okula Yabancılaşma, Güçsüzlük, Anlamsızlık, Kuralsızlık, Sosyal Soyutlanma.

\begin{abstract}
The purpose of this study is to examine the effect of the creative drama on the level of alienation of fifth grade students by means of students' theatre. The study was carried out in a public primary school in Ankara in 2008-2009 academic year. The study was conducted with 13 students (6 males and 7 females) who got the highest score in the "Student Alienation Scale (SAS)". In the study, 14 sessions (38 hours) have been made with the students. After these sessions, preparing a theatre performance in the framework of the workshop works has been decided. 24 hours preliminary work to the presentation stage and two general rehearsals for the pre-presentation have been made. In the preparation of this performance, a method which is named as "Children's Theatre" in the literature and occurred completely by means of creative drama has been used. As a result of the presentation works which have been made in accordance with the enactments in the workshop works, a theatre performance named "The School of Dreams and Realities" whose invitation card, text, name and scenery completely belonged to the students has been performed. The SAS was applied to these 13 students at the end of the performance as a post test. As a result of the data, statictically the question that whether the correlation between students alienation from school pretest and posttest scores were significant or not was checked through paired samples $t$-test. The significance level was accepted as.05. As a result, according to the findings achieved by means of the data collection tools, it has been found out that there is a significant difference between creative drama method and students' alienation scores and posttest scores are lower than their pretest scores.
\end{abstract}

Key Words: Creative Drama, Children's Theatre, Alienation from School, Powerlessness, Meaninglessness, Normlessness, Social Isolation.

* Bu makale, MEB Özel Doğaç Yaratııı Drama Liderliği/Eğitmenliği Kursu Bitirme Projesi'nden geliştirilerek yazılmıştır.

* Drama Lideri/Eğitmeni, E-posta: ozlemuzun2002@yahoo.com

** Çocuk Gelişimi ve Eğitimi Uzmanı/Drama Lideri, E-posta: serapmiya@hotmail.com 


\section{Giriş}

Her toplumsal kurum, ait olduğu toplumun beklentileri doğrultusunda değer-yaklaşım sistemlerini oluşturur. Bu toplumsal kurumlardan olan okulun üstlendiği görev açısından önemli bir yere sahip olduğu söylenebilir. Çünkü toplumların gelecek nesillerinin yetişmesinden resmî anlamda sorumlu olan tek sosyal kurum okuldur.

Okul, öğrenciye kendi gereksinim ve amaçlarıyla sosyal dünyasını bütünleştirerek doyum sağlayabilme olanağını hazırlar. Bunu gerçekleştirmek üzere okul, öğrenciye bağımsız düşünebilme yeteneğini geliştirmesi konusunda yardım eder (Yavuzer, 1998: s.155).

Ancak bu amaçların gerçekleştirilemediği ve birçoğunun sadece yazılı ilkeler olarak kaldığı bilinmektedir. Bunun sonucunda ise çocukta gelişmesi beklenilen özgüven, yaşama bağlılık, çevresinde olup bitenlere duyarlılık, risk alabilme, keşiflerden hoşlanma, kendisiyle ve çevresiyle barışık olma, soru sormaktan korkmama gibi bir çok beceriye çocukların sahip olamadıkları söylenebilir.

Freire (1998)'nin belirttiği gibi, okul içinde veya dışında, herhangi bir düzeydeki öğretmen-öğrenci ilişkisinin dikkatli bir analizi, bu ilişkinin temel olarak anlatı niteliğinde olduğunu ortaya koyar. Bu ilişki, anlatan bir özne (öğretmen) ve sabırla dinleyen nesnelerden (öğrenci) oluşur. Öğretmenlerin, öğrencilerin varoluşsal deneyimlerine tamamen yabancı bir konuda uzun uzadıya açıklamalar yaptıkları söylenebilir. Kelimeler, çocuklar için somutluklarından boşaltılır ve içi boş, yabancılaşmış ve yabancılaştırıcı bir laf kalabalığı hâline getirilir (Freire, 1998: s.50).

Okulların, öğrencilere içselleştiremedikleri bilgileri ve kuralları mekanik bir biçimde ezberletmeye çalıştığını geçmiş yaşantılarımızda gözlemlemişizdir. Öğrencinin okul deneyimini içsel olarak dönüştürememesinin, başka bir ifadeyle bu deneyimin genel yaşam pratiğinde karşıl1ğının anlaşılmamasının, onun bu süreçten -okul yaşantısından- soğumasına ve uzaklaşmasına nedenlerinden biri olduğu söylenebilir (Freire, 1998: s.51). Bu soğuma ve uzaklaşma, öğrencilerdeki yabancılaşma duygusunu daha da güçlendirebilir. Diğger yandan Bronfenbrenner (1986), bazı araştırmalarında, ailesel desteğin eksikliği, büyük vekişisel olmayan sınıflar, tüketici ve anında memnuniyeti vurgulayan kültürel etkinin de okula yabancılaşmanın en önemli sebepleri arasında yer aldığını belirtmiştir.

Yabancılaşma, oldukça eski bir kavramdır. Ancak okulda yabancılaşma, göreceli olarak yeni bir kavramdır ve öğrenci davranışını anlamada yeni kullanılmaktadır (Tusty ve Dooley Dickey, 1993). Genel anlamıyla yabancılaşma; insanın kendini kendi güç vezenginliğinin etkin yaratıcısı olarak değil de, dışındaki güçlere bağımlı, canlı özünü bu güçlere yansıtmış, yoksunlaşmış bir nesne olarak algılamasıdır (Fromm,1996: s.119). 
Tolan (1981) yabancılaşma kavramıyla ilgili birçok düşünürün teorileri olduğunu belirtmiştir (Akt. Bayhan, 1997: s.28). Ancak düşünürler arasından ilk olarak Seeman, yabancılaşmay1; güçsüzlük (powerlessness), anlamsızlık (meaninglessness), normsuzluk (normlessness), izolasyon (isolation), kendine yabancılaşma (self-estrangement) olmak üzere 5 kategoriye ayırmıştır.

Seeman, yabancılaşmanın boyutlarını belirleyerek bu olgunun ölçülebilir olması yönünde önemli bir katkı sağlamıştır. Diğer yandan Mau (1992) da, yabancılaşmayı "güçsüzlük, anlamsızlık, kuralsızlık ve sosyal uzaklık" olarak dört boyutta incelemiş ve bu boyutları öğrencilerin okullarda ne şekilde yaşadıklarını ortaya koymuştur. Bu boyutların okullarda ne şekilde yaşandığı kısaca şu şekilde özetlenebilir:

Güçüzlük: Öğrencinin kendi yaşamını kontrol etme ve bazı amaçları başarabilme konusunda düşük bir beklentiye sahip olması durumudur (Mau,1992).

Anlamsızlık: Öğrencinin geleceğe dair planları ile okulun öğrenciye sundukları arasında uyuşmazlık yaşanmasıdır (Oerlemans ve Jenkins, 1998).

Kuralsızlık: Öğrencilerin okul idaresinin kendilerinin yerine karar vermelerine karşı çıkmasıdır. Öğrenciler derslerdeki başarılarına göre sınıflandırıldıklarını düşünmektedirler. Bu şekilde sosyal bir karşılaştırmaya maruz kalan öğrenciler, doğal olarak okula karşı aidiyet duygusu geliştirememektedirler (Mau, 1992).

Sosyal Uzaklaşma: Öğrencilerin birtakım sosyal yabancılaşma belirtileri gösterdiği ve birçoğunun okul etkinliklerine dahil edilmediği saptanmıştır. Öğrenciler okulu, sorunlarını konuşabilecekleri bir yer olarak görmemektedir (Oerlemans ve Jenkins, 1998).

Yukarıda sıralanan yabancılaşma duyguları sonucunda pek çok öğrenci, topluma ve gelecekteki iş yaşantısına yeterince hazırlanamadan okuldan yavaş yavaş kopar ya da tamamen okulu bırakır. Dahası bu yabancılaşan öğrenciler toplumdan sosyal olarak soyutlanmış, yokluk içinde yaşayan siyasi olarak güçsüz yetişkinler hâlini alır (Duhm, 1996: s.85).

$\mathrm{Bu}$ faktörler göz önüne alındığında okulların mevcut atmosferlerini değiştirerek öğrencilerin yabancılaşmasını azaltmaya çalışmanın nesillerin geleceği için çok gerekli ve bir o kadar da zor bir iş olduğu söylenebilir. Okula yabancılaşan bir öğrencinin bu duygusunu azaltmak ya da tamamen ortadan kaldırabilmek için her şeyden önce bireyin yaşadığı şeyin farkına varması, bunun için de kendi içine dönerek kendinin farkına varabilmesi gerektiği söylenebilir. San (1990)'`n da belirttiği gibi insanın insanla giriştiği her tür dolaysız, doğrudan ilişki ve etki tepki alışverişine olanak sağlayan yegâne eğitim yöntemi olan yaratıcı dramanın bu sorunun çözümünde etkili bir yöntem olacağı düşünülebilir. Çünkü yaratıcı drama sürecinde, birey en çok "kendi”" olma durumunu yaşar ve bu süreç içerisinde; oyunlarla hayal gücünü geliştirme, kendi 
iç dünyasına bakabilme cesareti bulma, kedini ifade etmeye çalışan birisini anlamaya çalışma, yaşamla barışık olma ve insanı insana doğrudan yakınlaştırma değer yargılarını ve inançlarını yeni baştan düzenleme ve yaşamsal buluşma noktaları kendiliğinden yer alır (Üstündağ, 2002: s. 95).

Ancak okul kurumu, bir yandan en temel okuma-yazma aktivitelerini kazandırarak insanı özgürleştirdiğini ileri sürerken bir yandan da insanları birbirine benzeterek onların özgürlügüüü ellerinden almaktadır. Çocuklar okullarda, adına ders denen ve içinde bir sürü anlayamadığı kavram, terim ve bilgilerin yer aldığ 1 konu ve kitaplarla karşılaşmaktadır. Sosyal çevresinin yönlendirmesi ve okulun kaçınılmazlığı ile yetişmiş olan çocuk için, geriye hissedeceği tek bir duygu kalır: "Her şey doğru ve mükemmel, yanlış olan ve anlayamayan benim.” Bu duygu, her basamakta adım adım bütün benliğimizi sararak gelişir (Yapıcı, 2004) ve bunu sonucu olarak da bireyin okul yaşamı süresince önce kendine ardından da yaşadığı topluma yavaş yavaş yabancılaştığg ifade edilebilir. Buradan yola çıkılarak eğitim sistemine getirdiği yeni açılımlar ve özü itibarıyla yaratıcı dramanın bir yöntem ve disiplin olarak okullarda yer almasının kaçınılmaz bir ihtiyaç olduğu söylenebilir.

$\mathrm{Bu}$ ihtiyacın tam olarak karşılanabilmesi için bu alanda yeterli donanıma sahip eğitimciler tarafından, uygun mekânlarda yapılandırılmış drama oturumları hazırlanabilir. Çünkü yaratıcı drama ortamında katılımcılar yaratarak, düşünerek, algılayarak, geliştirerek ve yansıtarak kendilerini, arkadaşlarını, ailelerini ve içinde yaşadıkları gerçek dünyaya ait birçok şeyi anlayabilmektedirler (Fulford ve ark., 2001). Ayrıca yaratıcı drama ile çocuğun süreç boyunca kendini ve çevresini sorgulayabileceği, kendine dışardan bakma şansı bularak bir içgörü kazanabileceği ve birçok yaşantı geçirme şansını yakalayabileceği ifade edilebilir.

Okul kurumu, çeşitli nedenlerle kendini yenileyemediği, yeni ürünler ve düşünceler ortaya koyamadığı, dolayısıyla bunları gerçekleştirecek çağdaş insanı yetiştiremeyip onun doğal toplumsal, kültürel gereksinimlerine cevap veremediği sürece çağdaş bir niteliğe kavuşamaz (Adigüzel, 2006: s.203). Ve bu tip okullarda bireyin önce kendine daha sonra okul kurumuna ve insanlığa yabancılaştığı söylenebilir. İnsanların birbirlerine karşı duyduğu korkunç öfkenin nedeni, okulun yarattığg yabancılaşma ve onun sonucu oluşan "psikopatolojik toplu yabancılaşma" (Yapıc1, 2004) olduğu düşünülecek olursa bu çalışma ile yaratıcı dramanın okula yabancılaşma yaşayan ilköğretim 5. sınıf öğrencileri üzerindeki etkisinin çocukların tiyatrosu yoluyla incelenmesiyle problemin çözümüne katkı sağlanması amaçlanmıştır.

\section{Çalışmanın Amacı}

Bu çalışmanın amacı; yaratıcı dramanın okula yabancılaşma yaşayan ilköğretim 5. sınıf öğrencileri üzerindeki etkisinin çocukların tiyatrosu yoluyla incelenmesidir. Bu amaç doğrultusunda 
öğrencilerin yabancılaşma düzeyleri üzerinde yaratıcı dramanın anlamlı bir farklılık yaratıp yaratmadığı sorusuna yanıt aranmıştır.

\section{Yöntem}

Bu bölümde, araştırmanın modeli, çalışma grubu, kullanılacak veri toplama araçları yer almaktadir.

\section{Araştırmanın Modeli}

Bu çalışma, yaratıcı dramanın okula yabancılaşma yaşayan Çubuk İlköğretim Okulu 5. sınıf öğrencileri üzerindeki etkisini çocukların tiyatrosu yoluyla belirlemek amaciyla gerçekleştirilen deneme modelinde bir çalışmadır. Deneysel araştırma modellerinden biri olan tek grup öntest-sontest modeli kullanılmıştır. Karasar (2003)'ın da belirttiği gibi deneme öncesi modelin en önemli amacı öteki (gerçek ve yarı deneysel) daha iyi anlaşılmasını sağlamaktır. Araştırmada kullanılan deneysel modelin simgesel görünümü aşağıdaki gibidir.

$\mathrm{G}_{1} \quad \mathrm{O}_{1.1} \quad \mathrm{X} \quad \mathrm{O}_{1.2}$

Modelde $\mathrm{O}_{1.2}>\mathrm{O}_{1.1}$ olması halinin "X" den dolayı olduğu kabul edilir. Ancak grubu etkilemesi olası öteki değişkenlere ilişkin bir şey bilinmediğinden geçerliliği sınırlıdır.

\section{Çalışma Grubu}

Bu çalışmanın örneklemini, okula yabancılaşma yaşayan Çubuk İlköğretim Okulu 5. sınıf kız ve erkek öğrencileri oluşturmaktadır. Uygulanan Öğrenci Yabancılaşma Ölçeği (ÖYÖ) sonucunda, yabancılaşma puanı en yüksek olan 6'sı erkek, 7'si kız toplam 13 öğrenci çalışmanın katılımcılarını oluşturmuştur.

$\mathrm{Bu}$ öğrencilerin aile yapılarına bakıldığında hepsinin düşük sosyoekonomik seviyede olduğu görülmektedir. Bölgenin feodal ve tutucu bir yer olması nedeniyle aileden alınan eğitimle okuldaki doğrular arasındaki öğretinin yarattığı gerginlik ve cinsiyetler arasındaki ayrım problemi çok belirgin olarak yaşanmaktadır. Ayrıca ailede fiziksel şiddet, aşırı ilgisizlik ya da kontrolsüz aşırı ilgi, öğrencilerin durumları ile ilgili saptanan diğer problemlerdir.

\section{Veri Toplama Aracı}

Araştırmada veri toplama aracı olarak araştırmacı tarafından geliştirilen Öğrenci Yabancılaşma Ölçeği (ÖYÖ) uygulanmıştır. Nicel verilerin yanı sıra çalışma sonunda tüm katılımcılara ve on- 
ların sınıf öğretmenlerine sürece dair birer mektup yazdırılarak nitel veriler de elde edilmiştir.

\section{Verilerin Analizi}

Deney grubuna uygulama öncesi ve sonrasinda toplanan verilerin analizinde, SPSS-11.6 istatistik programı kullanılmıştır. Analizler her alt ölçek puanı için ayrı ayrı yapılmıştır. Analizlerde deney grubunun ön test-son test puanlarının aritmetik ortalamaları alınmış, puanları arasındaki farkın anlamlı olup olmadığını istatistiksel olarak da tespit etmek üzere ilişkili örneklemler için t-testi analizi yapılmıştır.

\section{Uygulama}

Çalışmanın ilk aşamasında öğrencilerin okula yabancılaşmaları ve yabancılaşmaya neden olan etkenler araştırılmıştır. Elde edilen bilgiler 1şığında, öğrencilere uygulanan yaratıcı drama oturumları yapılandırılmıştır. Öğrencilerin okula karşı yabancılaşma duygularını azaltmaya yönelik oturumlar yapılandırılırken program geliştirme sürecinin ögeleri ve değerlendirme dikkate alınmıştır. İçeriğin eğitim programının ögeleriyle ilişkisi Şekil 1'de gösterildiği gibi biçimlendirilmiştir. 


\section{AMAÇLAR (NEDEN)?}

Öğrencilerin okula yabancılaşma düzeylerini azaltma.

Okulu anlamlı kılma.

Okula aidiyet hissetme.

Kendi görüş ve düşüncelerini değerli bulma.

Yaşantılarına ilişkin görüşlerini açıkça ifade etme.

İstenilen nitelikte canlandırmalar yapma. Atölye çalışmalarından oluşan bir gösteride yer alma.

\begin{tabular}{|l|}
\multicolumn{1}{c|}{$\begin{array}{l}\text { YAKLAŞIM/YÖNTEM/ TEKNIKK } \\
\text { (NASIL)? }\end{array}$} \\
Yaratıcı Drama, \\
Rol Oynama, \\
Doğaçlama, \\
Fotoğraf Anı, \\
Anlatım, \\
Soru-Cevap, \\
Donuk İmge, \\
Dramatizasyon, \\
Pandomim, \\
Liderin Role Girmesi. \\
\end{tabular}
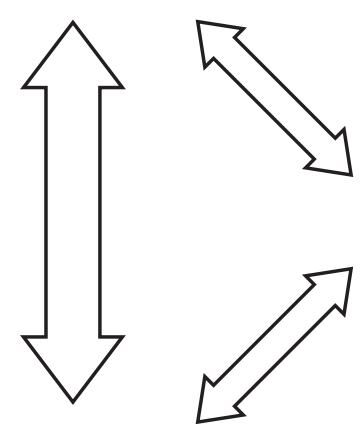

\section{İÇERİK (NE)?}

Tanışma ve Projenin Tanımı

Tanışma ve Kendini Tanıma

Grup Dinamiği Oluşturma ve Güven

çalışmaları

Güven Çalışması

Görme Algisı

Dokunma Algisı

Dans ve Hareket Çalışması

Dans ve Öykü Çalışması

Özgün Oyunlar Üretme

Öykü Oluşturma Çalışması

Güçsüzlük Duygusunun Farkına Varma

Farklı Duyuları Ayırt Etme

Yabancılaşmaya Sebep Olan Okul Yaşantıları

Kuralsızlık Duygusu

Sahneleme Çalışmaları
ÇALIŞMA GRUBU (KIMLER)?

Okula Yabancılaşma

Yaşayan Çubuk İ.Ö.O.

5. Sinıf Öğrencileri

(13 Katılımc1)

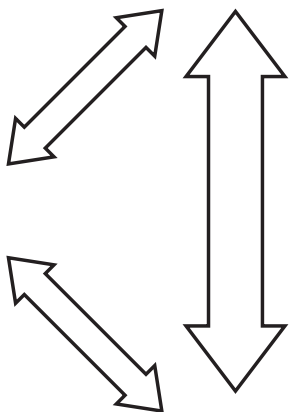

\section{ÖLÇME DEĞERLENDİRME} (NE OLDU)?

Ön - Test Son - Test

Oturum Değerlendirmeleri

Öğrenci Mektupları

Öğrencilerin Sınıf Öğretmenlerinin Görüşleri

Oyun Metni

Oyun CD'si

Oyun Afişi

Oyun Davetiyesi

Şekil 1: Yaratıcı Drama Temelli Ders Planlarının Dayandı̆̆ı Program Geliştirme Aşamaları 
Öğrencilerle toplam 38 saatlik on dört oturum yapılmıştır. Bu oturumların ardından yapılan atölye çalışmalarından yola çıkılarak bir tiyatro gösterisi hazırlanmasına karar verilmiştir. $\mathrm{Bu}$ gösterinin hazırlanmasında literatürde "Çocukların Tiyatrosu" olarak geçen ve tamamen yaratıcı drama ile gerçekleşen bir yöntem kullanılmıştır. Burada önemli olan çocuktur. Çocuk, kendi oyununu kendisi yazar ve oynar. Okula karşı yabancılaşma yaşayan öğrencilerin seslerini daha iyi duyurabilmeleri, kendilerine "Ben başardım." diyebilmeleri, birlikte bir şeyler yapıp sonuca varabilme sorumluluğunu ve manevi hazzını yaşayabilmeleri ve son olarak yabancılaşma yaşadıkları okullarına aidiyet hissedebilmeleri için bu çalışma yapılmıştır. Bu doğrultuda grup üyeleri oyunun ismine "Hayaller ve Gerçekler Okulu” olarak karar vermişlerdir. Ayrıca öğrenciler; oyunun davetiyesi, metni, adı, dekoru ve kostümünün yanı sıra yine sözleri kendilerine ait müzikli bir dans gösterisi hazırlamışlardır. Oyunun sahneleme aşaması 24 saatlik ön hazırlıkla gerçekleşmiştir. Bunun yanısıra sahneleme öncesinde iki kez genel prova yapılmıştır.

\section{Bulgular ve Yorum}

\section{Anket Sonuçlarına Yönelik Bulgular}

Öğrencilere çalışma öncesinde uygulanan ÖYÖ, çalışma bitiminde tekrar uygulanmış ve elde edilen puanlar Sosyal Bilimlerde Veri Analizi (SPSS) programına yüklenerek gerekli analizler yapılmıştır. Öğrencilerin ön ve son teste verdikleri cevaplar puanlanarak her öğrencinin aldığ 1 aritmetik ortalama puanları Tablo 1'de karşılaştırılmıştır.

Tablo 1: Öğrencilerin Ön Test- Son Test Puanlarının Aritmetik Ortalamaları

\begin{tabular}{|c|c|c|c|c|c|c|c|c|c|c|c|c|c|}
\hline & 1.öğr. & 2.öğr. & 3.öğr. & 4.öğr. & 5.öğr. & 6.öğr. & 7.öğr. & 8.öğr. & 9.öğr. & 10.öğr. & 11.öğr. & 12.öğr. & 13.öğr. \\
\hline $\begin{array}{l}\text { Ön } \\
\text { test }\end{array}$ & 48 & 46 & 50 & 41 & 37 & 45 & 35 & 39 & 37 & 41 & 46 & 53 & 49 \\
\hline $\begin{array}{l}\text { Son } \\
\text { test }\end{array}$ & 30 & 28 & 30 & 20 & 30 & 28 & 31 & 32 & 20 & 16 & 19 & 19 & 15 \\
\hline
\end{tabular}

Öğrencilerin yabancilaşmanın güçsüzlük alt ölçeğine (2.,4.,6.,9.,11.,13.,14. maddeler) verdikleri cevapların aritmetik ortalamaları alındığında ön test (24.23) ve son test (12.92) puanlarının aritmetik ortalamaları arasında anlamlı bir fark olduğu görülmektedir. Bu sonuç, bizlere “öğrencinin kendi yaşamını kontrol etme ve bazı amaçları başarabilme konusunda düşük bir beklentiye sahip olması" (Mau, 1992) durumunu ifade etmekte olan güçsüzlük duygusunun öğrenciyi rekabete zorlamayan, "Ben yaptım, ben başardım.” diyebilme olanağı sunan yaratıcı 
drama yoluyla azaltılabileceğini göstermektedir.

Kocayörük (2000), yeterince sosyal davranış gösteremeyen ilköğretim öğrencilerinin sosyal becerilerini geliştirmede dramanın etkisini incelemiş ve dramanın öğrencilerin sosyal becerilerinin gelişmesinde etkili olduğu sonucuna ulaşmıştır (Akt. Bayer, 2006: s.38).

Öğrencilerin, yabancılaşmasının anlamsızlık alt ölçeğinden (3.,8.,10. maddeler) aldıkları puanların aritmetik ortalamalarına bakıldığında ön testte 8.3 iken son testte 5.0'a düştüğü Tablo 3 'de görülmektedir. Loken (1973)'e göre, öğrenciler sınıfta ya da okulda yapılan etkinlikleri kendi kişisel amaçlarına ulaşmakta yardımcı olacak araçlar olarak göremediklerinde anlamsızlık duygusunu yaşamaktadırlar (Uzun, 2006: s. 29). Yaratıcı drama çalışmaları sonucunda öğrencilerin anlamsızlık puanlarının düşüş göstermesinin sebebi olarak, dramanın öğrenme sürecinde çocuğu etkin kılması ve bu öğrenme sürecine çocuğun duyuşsallığı ve yaşantılarını katabilmesi gösterilebilir. Bunun sonucunda da birçok araştırma göstermiştir ki çocuğun akademik başarısı olumlu yönde değişim göstermiştir.

Örneğin, Aykaç ve Adıgüzel (2011)'in araştırması, ilköğretim 4. sınıf Sosyal Bilgiler Dersi, “Gruplar, Kurumlar ve Sosyal Örgütler” öğrenme alanına bağlı "Hep Birlikte" temasının yaratıcı drama yöntemiyle işlenmesinin, öğrencinin başarısını ne ölçüde etkilediğini ortaya çıkarmayı amaçlamaktadır. Uygulamadan elde edilen sonuçlara göre drama yöntemi ile dersi işlenen kontrol grubunun başarısının daha yüksek olduğu bulunmuştur. Ayrıca bu çalışmada nitel veriler de değerlendirilmeye alınmış, öğrencilerden alınan değerlendirme formları incelenmiştir. Öğrencilerin verdikleri cevapların içerik analizi sonuçlarına göre, diğer yöntemlere göre daha iyi öğrendikleri, konuyu daha iyi anladıkları, Sosyal Bilgiler dersini daha çok sevdikleri ve öğrenme sürecinde mutlu oldukları anlaşılmıştır (Malbeleği, 2011: s.61).

Yabancılaşmanın kuralsızlık alt ölçeğinden (1.,12. maddeler) alınan puanların aritmetik ortalamalarına bakıldığında bu puanların ön testte 5.23 iken son testte 3.38 'e düştüğü Tablo 3 'te görülmektedir. Kuralsızlık yaşayan çocuğun okulda kendinden beklenen hedeflere ulaşmak için zaman zaman her yolu geçerli gördüğü söylenebilir. Aynı şekilde Mau (1992)'ya göre bu çocuklar okullarda akademik başarılarına göre sınıflandırılmaları ve sosyal bir karşılaştırmaya maruz bırakıldıklarını düşünmeleri nedeniyle okula karşı aidiyet duygusu hissedememekte ve kuralları reddetmektedirler (Akt. Uzun, 2006: s.5). Yaratıcı drama çalışmaları sonucunda bu çocukların kuralsızlık duygularında azalma olmasının nedeni; dramanın öğrenciyi başarılı-başarısız şeklinde sınıflandırmaması, öğrenci tarafından ortaya konan ürüne saygı gösterilerek bir kıyaslama yapılmaması ayrıca atölye çalışmalarında ve onun uzantısı olan tiyatro gösterisinde kuralların yaşamdaki yerini kendi yaşantılarından yola çıkarak sorgulama şanslarının olması gösterilebilir. Çocuğun kurallara uyumunu sağlamada empati becerisinin gelişmiş olması katkı 
sağlayabilir. Çünkü "Çağdaş insanın getirdiği iletişim sorunlarına, yalnızlığa ve yabancılaşmaya karşı en etkili yol insanların birbirlerini anlamaya çalışmalarıdır. Bu anlamayı sağlayan en etkili yol ise kişinin kendisini karşısındakinin yerine koyarak, onun duygu ve düşüncelerini anlamaya çalışarak, yani empati kurarak anlamasıdır" (Dökmen, 1987; Akt: Okvuran, 1995: 188). Yaratıcı dramanın içerisinde sürekli bir etkileşim ve etkinlik vardır. Özellikle doğaçlama tekniği, bireyin empati becerisini geliştirebilecek en önemli tekniklerden birisidir. Bu etkinliklerle birey, kendini özgürce ifade edebilme firsatı bulur. Birey, yeni deneyimler kazanarak yaşantı zenginliği edinmiş olur böylece iletişim becerilerinde gelişme sağlanabilir (Oğuz ve Altun, 2011: s. 2).

Son olarak yabancılaşmanın sosyal soyutlanma alt ölçeğinden alınan puanların aritmetik ortalamalarına bakıldığında ön testte alınan puan 5.84 iken bu puanın son testte 3.0'a düştüğü görülmektedir. Öğrencinin sosyal yabancılaşma yaşamasının en önemli sebeplerinden biri okul etkinliklerine dâhil edilmemesidir. Ayrıca bu öğrenciler kendilerini sosyal açıdan yalıtılmış hissederler, yalnızlığı severler ve okul faaliyetlerine katılmazlar (Oerlemans ve Jenkins, 1998). Okulların sosyal aktiviteler dâhil hemen tüm etkinliklerde akademik başarısı yüksek ya da kendini çok iyi ifade eden, topluluk içinde sivrilen kısacası "popüler" çocukları tercih ettiği hepimizin bildiği bir gerçektir. Bu nedenle arada kalmış, kendi becerilerini keşfedememiş, sınıfta sessizce oturup sadece izlemekle yetinen çocukların doğal olarak yaşadıkları sosyal ortama karşı yabancılaşma yaşadıkları söylenebilir. Bu çocukların kendi akranları arasında da kabul görmeme problemi yaşamakta oldukları bilinmektedir. Yaratıcı drama çalışmalarına katılan çocukların sosyal soyutlanma duygularında da azalma olduğu görülmektedir. Çünkü yaratıcı drama, bireyin kendini gerçekleştirmesi için birlikte çalışma ve sorumlulukları paylaşma firsatını vermektedir (Adıgüzel, 2006: s.245).

Akın (1993) da yaptığı çalışmada farklı sosyo ekonomik düzeylerdeki ilkokul üçüncü sınıf öğrencilerinin sosyalleşme düzeylerine yaratıcı drama eğitiminin etkisi olup olmadığını araştırmış ve yaratıcı drama eğitimi almanın sosyalleşme düzeyleri üzerinde anlamlı bir değişiklik yarattığ1 sonucuna ulaşmıştır (Akt. Bayer, 2006: s.38).

\section{Öğrencilerin Süreç Sonunda Yazdıkları Mektuplara Yönelik Bulgular}

Çalışma sonunda öğrencilerden, yaşadıkları sürece dair duygu ve düşüncelerini anlatan bir mektup yazmaları istenmiştir. Öğrenciler mektuplarda genel olarak; memnuniyet, grup arkadaşlarına dair cinsiyet ayrımı gözetmeksizin içten ve samimi duygular, başarmış olmanın verdiği haz, benzer bir çalışmanın içerisinde tekrar olma isteği, öğretmenlerine karşı olumlu duyguları anlatan ifadelere yer vermişlerdir. Öğrencilerin mektuplarında yer alan bazı satırlar aşağıdaki gibidir: 
"Drama bittiği için çok üzüldüm ama düşünüyorum da ben bir tiyatro aşığı oldum. Sizi de arkadaşlarımı da çok seviyorum. Siz bize ne bağırdınız ne de kızdınız. Hep beraber güldük hep beraber oynadık. Bizi sevdiniz ve sevindirdiniz."

"Drama benim hayatım ve ben artık hayatımdan kopamam. Drama beni benden aldı kendime olan güvenim sonsuz oldu. Evde ve okulda geçirdiğim sorunlarımı unuttum.”

"Ben dramaya sonradan katıldım şişmanlık derdimi unutmak için çaba sarfettim kendimi sevebilmek için de ve başardım."

"Drama hayatın bir parçası her çocuğa lazım özellikle de sıkıntıları ve tiyatro yeteneği olup kullanamayan çocuklar için."

"Bu sene sizin sayenizde karnem kötü olsa da çok sevinçliyim. Çünkü dramada aldığımız teşekkür belgesi karne notlarımızdan bile daha değerli. O sevinci bize yaşattırdığınız için size çok teşekkür ediyorum.”

"Büyüdüğümde çocuğum olursa muhakkak dramadan, drama arkadaşlarımdan ve sizden bahsedeceğim. Çocuğumun da drama eğitimi almasını ve o sevgiyi yaşamasını çok isterim.”

\section{Sonuç ve Öneriler}

Bu proje, yaratıcı drama yönteminin, okula yabancılaşma yaşayan ilköğretim 5. sınıf öğrencilerinin yabancılaşma düzeyleri üzerindeki etkisinin, çocukların tiyatrosu yoluyla incelenmesini içermiştir.

Çalışmaya 13 öğrenci katılmıştır. Bu katılımcılar Uzun (2006)'un geliştirdiği öğrenci yabancılaşma ölçeğinden (ÖYÖ) alınan puanlara göre seçilmiştir. Çalışmalar öncesinde yabancılaşma puanları yüksek olan öğrencilere aynı ölçek çalışma sonunda tekrar uygulanarak arada anlamlı bir fark olup olmadığı incelenmiştir. Bunun sonucunda öğrencilerin yabancılaşma puanlarının düştüğü görülmüşsür. Atölye çalışmalarında yapılan değerlendirmelerden, gözlemlerden, öğrencilerin çalışma sonunda yazdıkları mektuplardan, öğrencilerin sınıf öğretmenlerinin kişisel görüşlerinden, sergilenen oyundan ve anket sonuçlarından yola çıkılarak bu çalışmanın istenilen hedefe ulaştığı söylenebilir.

Okulların ya da öğretmenlerin başarısının genel olarak iyi öğrencilerin sayısı ile ölçüldüğünü düşünecek olursak, gözden kaçan arada kaynayan, mutsuz, şiddet eğilimli, isteksiz, kuralları reddeden, uyum güçlüğü yaşayan, kendinden, okuldan duygusal açıdan uzak ve bunlara bağlı olarak genelde akademik başarıları düşük olan bu öğrencilerin gelecekte çok ciddi problemler yaşama ve yaşatma riski taşıyacağı düşünülebilir. Bu çocuklar geleceğin "mutsuz ve umutsuz 
yetişkinleri” olarak karşımıza çıkabilir. Onların okul kurumundan en iyi düzeyde faydalanmalarını sağlayacak çözüm önerileri üretmek eğitimcilerin görevi olmalıdır. Bu çalışmayla yaratıcı dramanın ve onun uzantısı olan çocukların tiyatrosunun yabancılaşma duygusunu azaltmaya ne derece katkı sağlayabileceği belirlenmeye çalışılmış ve anlamlı düzeyde sonuçlar elde edilmiştir. Bu nedenle çalışmadan elde edilen sonuçlara dayalı olarak aşağıda uygulamalar ya da gelecekte yapılacak çalışmalara yönelik önerilere yer verilmiştir.

- Projeden elde edilen sonuçlardan yola çıkılarak öğrencilerin yabancılaşma duygularını azaltmak amacıyla yaratıcı drama çalışmaları daha fazla düzenlenebilir.

· Bu çalışma ilköğretim 5. sınıf öğrencileri ile yapılmıştır. Aynı çalışma farklı yaş gruplarıyla da yapilabilir.

· Öğgrenci yabancılaşmasının yanı sıra, öğrencinin okul yaşamını büyük oranda etkileyen ve okula karşı tükenmişlik yaşayan öğretmenlerle de benzer bir çalışma yapılabilir.

• Okula yabancılaşmayı tetikleyen "köyden kente göç, ders içeriği, anne-baba tutumu" gibi diğer faktörlerden biri ya da bir kaçını kapsayan çalışmalar öğrenci yabancılaşmasının azalmasına katkı sağlayabilir.

- Yabancılaşma yaşayan öğrencilerle yapılacak çalışmada problemin nedenlerinin çok fazla değişkene bağlı olması nedeniyle uygulamaların uzman kişilerden oluşan bir ekiple gerçekleştirilmesi çalışmanın daha sağlıklı yürütülmesinde etkili olabilir.

- Yaratıcı drama yoluyla çocuklar tarafından çocuklara sergilenen nitelikli tiyatro oyunları üretilmesi çocuk dünyasını anlamada önemli bir araç olabilir.

- Bilimsel geçerliliğini artırmak için çalışma, gerçek deneme modeli ya da yarı deneme modeli kullanılarak tekrarlanabilir.

· Bu projeye, eğitimciler için bir örnek teşkil etmesi nedeniyle Milli Eğitim Bakanlı̆̆ı'nın hizmet içi eğitim programlarında yer verilebilir.

\section{Kaynaklar}

Adıgüzel, Ö. (2006). (Ed.). Yaratıcı Drama 1985-1998 Yazılar (2. Baskı). Ankara: Naturel Kitap Yayın Dağıtım.

Akfırat, Önalan, F. (2006). Sosyal yeterlilik, sosyal beceri ve yaratıcı drama, Yaratıcı Drama Dergisi Cilt 1, Sayı 1

Bayer, M. (2006). "Sokak Çocuklarının Eğitiminde Drama ve Tiyatro'nun Kullanılması ve Bir Uygulama.": Yüksek Lisans Tezi, Ankara Üniversitesi Sosyal Bilimler Enstitüsü Tiyat- 
ro Anabilim Dall, Ankara.

Bayhan, V. (1997). Üniversite Gençliğinde Anomi ve Yabancılaşma, Kültür Bakanlığı Yayınları, Ankara: Filiz Matbaası.

Bronfenbrenner, U. (1974). The Origins of Alienation. Scientific American, 231, 53-61.

Dökmen, U.(1987). Empati kurma becerisi ile sosyometrik statü arasındaki ilişki. A. ̈.

E.B.F. Dergisi, 20(1-2),183-2007.

Duhm, D. (1996). Kapitalizmde Korku (2. Bask1), (Çev.Sorgut Sölçün), Ankara: Ayraç Yayınevi, Psikolojik Kitaplar Dizisi.

Freire, P. (1998). Ezilenlerin Pedagojisi (Üçüncü Basım), (Çev.: D. Hattatoğlu-E. Özbek), İstanbul: Ayrıntı Yayınları.

Fromm, E. (1996). Sağlıklı Toplum (3. Basım), (Çev.: Yurdanur Salman-Zeynep Tanrısever), İstanbul: Payel Yayıncılik.

Fulford, J., Hutchings, M., Ross, A. \& Schmitz, H. (2001). Ilköğretimde Drama (1. Basım). (Çev. Leyla Küçükahmet, Hande Borçbakan, S. Sadi Karamaoğlu). Ankara: Nobel Yayın Dağıtım.

Karasar, N. (2003). Bilisel Araştırma Yöntemleri (12. Basım), Ankara: Nobel Yayınları

Loken, J.O. (1973). Student Alienation and Dissent. Critical Issues In Canadian Education Series.

Malbeleği, F. (2011). "Drama Yönteminin Sosyal Bilgiler Dersi Başarısına ve Bilinçli Tüketicilik Üzerine Etkisi.": Yüksek Lisans Tezi, Sakarya Üniversitesi Eğitim Bilimleri Enstitüsü, Sakarya.

Mau, R.Y. (1992). “The Validity And Devolution of Concept: Student Alienation.” Adolescence, vol. 27 Issue 107, p731-741.

Nutku, Ö. (2006). Oyun, Çocuk, Tiyatro (İkinci Basım). Ankara: Özgür Yayınları.

Oğuz, A., ve Altun, E.(2011). Öğretmen adaylarının yaratıcı dramaya yönelik tutumları ile empatik eğilim düzeyleri arasındaki ilişkinin düzenlenmesi, 2. International Conference on New Trends in Education and Their Implications, 27-29 April, 2011 Antalya-Turkey.

Oerlemans, K ve Jenkins, H. (1998). “There are aliens in our school.” Issues in Educational Research, 8(2), 117-129.

San, İ. (1990), Eğitimde Yaratıcı Drama. Ankara Üniversitesi Eğitim Bilimleri Fakültesi Dergisi, 23, 573-582.

Trusty, J. ve Dooley-Dickey, K. (1993). "Alienation from School: An Exploratory Analysis of Elementary and Middle School Students Preceptions." Journal of Research and Development in Education, v.26 n.4 p.232-42. 
Uzun, Ö. (2006). “İlköğretim 5. Sınıf Öğrencilerinin Okula Yabancılaşma Düzeylerine Etki Eden Sosyo-Demografik Değişkenlerin Belirlenmesi." : Yüksek Lisans Tezi, Çukurova Üniversitesi Sosyal Bilimler Enstitüsü, Adana.

Üstündağ, T. (2002). Yaratıcı Drama Öğretmenimin Günlüğü (2.Bask1). Ankara: Pegem Yayincilik.

Yapıc1, M. (2004). "Eğitim ve Yabancılaşma.” Uluslar arası İnsan Bilimleri Dergisi, ISSN: 1303-5134.

Yavuzer, H. (1998). Çocuk Psikolojisi (15. Basım), İstanbul: Remzi Kitapevi.

\section{EK 1: Farklı Duyguları Ayırt Edebilmeyi Konu Alan Oturum İçeriği}

Mekân: Çubuk İlköğretim Okulu Drama Dersliği

Konu: Farklı Duyguları Ayırt Etme

Katılımcılar: 5. Sınıf Öğrencileri

Süre: 3 saat

Araç ve Gereçler: Shantel "Disko Partizan”, top, kâğıt, kalem.

Yöntem:Yaratıc1 Drama

Teknik: Doğaçlama, Rol oynama, Pandomim, Donuk İmge

\section{Kazanımlar:}

1. Beden dilini kullanarak kendini ifade eder.

2. Anlatma istediklerimizin çevremizdekiler tarafından farklı algılanabileceğinin farkına varır.

3. Okulda değiştirmek istediği durumlar hakkında düşünür.

4. Kendini sözlü olarak ifade eder.

\section{Isınma-Hazırlık}

1. Grupla "Davul Zurna Bir İki Üç” oyunu oynanır. Tüm grup çember olur. Grup üyelerinden biri "davul” diyerek oyunu başlatır. Diğer sözcükler olan; zurna, bir, iki ve üçü sırayla diğer grup üyeleri söyler. Burada sözcükleri seri hâlde söylemek önemlidir. Yanlış sözcüğü söyleyen çocuk gruptan ayrılmadan olduğu yere oturur ve ayaktakiler oyuna devem eder. Oyun, yeteri kadar oynanmasının ardından lider tarafından uygun bir zamanda sonlandırılır.

2. Ardından gruptakiler ikili olarak eşleşirler. Biri heykeltıraş, diğeri heykel olur. Heykeltıraşlar heykel olana, bir duygu ya da düşünceyi ifade eden bir biçim verir. Heykel olan kendini serbest bırakmalıdır. Heykel tıraş da arkadaşının bedenine zarar vermeden çalışmalıdır. Heykeller tamamlanınca heykeltıraşlar yanlara çekilir. Odanın farklı yerlerinde heykeller donmuş olarak dururlar. Lider ve heykeltıraşlar sergiyi gezerler, her heykelin neyi ifade ediyor olabileceği üzerine konuşurlar. Aynı çalışma eşler değiştirilerek tekrarlanır. 


\section{Ara Değerlendirme}

Heykeltıraşlara lider tarafından, "Sizin ifade etmek istediğiniz duygu ya da düşünce ile heykeliniz hakkında konuşan arkadaşlarınızın ifade ettikleri arasında ne tür benzerlikler ya da farklılıklar vardı?” sorusu yöneltilir.

\section{Grup Üyelerinin Paylaşımları}

"Düşüncemi heykele aktarmakta zorlandım ama arkadaşlarım düşündüğüm duyguya yakın şeyler söylediler. Mutlu oldum.”, "Bana göre çok güzel ve benim düşüncemi anlatan bir heykeldi ama kimse aynı şeyi anlamamış.", "Kafamdan birçok duygu geçmişti o nedenle heykelimde karışık oldu galiba.", "Çalışma tekrarlanınca ben herkes anlasın diye çok belirgin bir düşünce seçmiştim, herkes de doğru tahminde bulundu.", "Benim duygumla arkadaşlarımın söyledikleri arasında hiçbir benzerlik yoktu, bu duruma sinir oldum."

3. Grup ikiye ayrılır ve lider tarafından verilen ifadelerle sessiz film oynamaları istenir. Buna göre Birinci gruba: "Tatil Ödevi, Dersini Yapmamış Öğrenci, Çirkin Ördek Yavrusu”, ikinci gruba: "Mutsuz Kedi, Kitabını Unutan Öğrenci, Bozuk Televizyon” ifadeleri verilir.

\section{Canlandırma}

1. Lider gruba: "Hayatta her insanın değiştirmek istediği şeyler vardır. Hem büyüklerin hem küçüklerin. Şimdi sizlerden istediğim, okulda değişmesini isteyip de değiştiremediğiniz bir şey düşünün ve onu sizlere vereceğim kâğıda yazarak salonun bir kenarına arkasını çevirip birakın." der.

2. Bu çalışmanın tamamlanmasının ardında lider gruba: "Şimdi sizlere bir top vereceğim müzikle (Shantel "Disko Partizan") birlikte hem dans edeceksiniz hem de topu elden ele dolaşt1racaksınız. Müzik durduğunda top kimin elinde kalırsa o gidip arkası dönük kağıtlardan bir tane alarak söz kullanmadan tıpkı sessiz film oynar gibi guruba canlandırarak anlatacak. Eğer isterseniz canlandırmanızda yardımcı arkadaş seçebilirsiniz.” der. Burada izleyicilerin canlandırma bitene kadar kesinlikle tahminde bulunmamaları gerektiği de belirtilir. Gruptaki herkesin katılımı sağlanarak kağıtlardaki tüm ifadeler canlandırıldıktan sonra çalışma sonlandırılır.

\section{Grup Üyelerinin Paylaşımları}

Çocukların okulda değiştirmek isteyip de değiştiremeyeceklerini düşündükleri durumlar şunlar olmuştur: "Okul bahçesi yeşillik olsa, çok yazı yazmasak, beş dakika ders kırk dakika teneffüs olsa, okul kantini kafe gibi olsa, çantam daha hafif olsa, tek sırada yayılarak otursam, okula çantasız gitsem, okul bahçesi kocaman olsa, teneffüslerin süresi artsa, yazı yazmaktan kurtulsam, dersleri bahçede yapsak." 


\section{Değerlendirme}

Lider gruba iki soru yöneltir. Bunlardan ilki: "Bu çalışmada hangi duyguları hissettiniz?", diğeri: "Bu çalışma sizlere neleri düşündürdü?"

\section{Grup Üyelerinin Paylaşımları}

Bu çalışmada genel olarak: "mutluluk, sinir, heyecan, savaş, umutsuzluk, rahatlama, umut, şaşkınlık” duygularının yaşandığı ifade edilmiştir.

Bu çalışmada: "Heykeltıraş olmayı düşündüm.,",Kendimizi anlatmanın zor olduğunu düşündüm.”, "Tiyatrocu olmayı istedim.”, "Sabırlı bir insan olmadığımı anladım”, "Bir şey için uğraşırsam yapabileceğimi düşündüm.”, “Okulda ne çok sorunumuzun olduğunu düşündüm.", "Hepimizin farklı probleminin olduğunu anladım.", "Okulda beni mutsuz eden şeyin ne olduğunu buldum.", "Sürekli birbirimizin ne anlattığını anlamaya çalıştığımızı fark ettim." şeklindeki dönütler, katılımcılardan alınmıştır. 


\title{
Summary \\ A Treaty on the Effect of Creative Drama Through the Theater of Children on K-5 Students Who Experience Alienaton to Their School
}

\author{
Özlem YILMAZ* $\quad$ Serap ANTEPLI
}

The Purpose of the Study

This study intends to investigate the effect of creative drama through the theater of children on K-5 students who experience alienaton to their school and aimed to search for an answer to whether there was a significant difference on the effect of creative drama on the level of students' alienation to the school.

\section{Significance of the Study}

As a result of the literature review, it has been found out that the studies regarding the students' alienation to schools, especially those who attend Grade 1, are quite recent and often ignored. However, the studies abroad indicate that alienation to school starts at early stages of schooling (Uzun, 2006: p.15). The students who experienced alienation showed that one of the reasons was that the school seemed a heavy burden for them. Generally the attitude of the school is based on the facts that they lack understanding the real underlying cause of the problem and are quite far from finding realistic solutions or find only momentary or superifical solutions. It can be stated that those students are often punished and the reason why they behave in that way is often ignored and they are not presented any opportunity in order to express themselves.

Creative drama can be considered a tool in order to enable students to understand themselves and the environment and to provide a chance to help them to reduce their alienation level to schools as well as question themselves.Alienation that has caused a lot of social and educational problems such as violence, crime, vandalism, failure, low success, indifference, absenteeism, hatred to schools has commenced to culminate after 1968 ( (Tezcan, 1983). Therefore, any action or precaution that prevents students from alienating to the first institution, namely schools, where the first stages of alineation are experienced can be regarded as a contribution to the field itself.

In this sense, creative drama that helps students perceive the world they live in more vividly and tansform abstract concepts or epxeriences into concrete life experiences can be counted as an alternative method or an art discipline so as to reduce the negative feeling of estrangement

\footnotetext{
* This article was written from MEB Dogac Creative Drama Leadership's Educator's Course Final Project.

* Drama Leader, e-mail: ozlemuzun2002@yahoo.com

** Child Development and EducationSpecialist/Drama Leader, E-mail:serapmiya@hotmail.com
} 


\section{Sampling}

The participants of the study were composed of the male and female K-5 students who experienced alienation at Çubuk Primary School. After conducting the alienation scale, the results showed that the highest score obtained from alienation scale consisted of the six males and 7 females, totally 13 students.

\section{Data Collection Instruments}

As a data collection instrument, a pretest and posttest developed as the scale of student alienation by Uzun (2006) were conducted. In additon to the scale, at the end of the sessions, the letters, the script composed by the participants, $\mathrm{CD}$, flyers and invitation cards also constituted the qualitative aspect of the study.

\section{Results and Implications}

This project included creative drama through children's theater in order to analyze the K-5 students' level of alienation to schools. 13 students participated in the study. The students were selected according the scale developed by Uzun (2006). Those who were given the scale before the study was re-administered after the study in order to find out whether there was a significant difference between the pre and post study. The post test showed that there was a significant difference in that the score of alineation decreased.In additon to the results of the study, the qualitative inquiry indicated that the study reached the goal aimed before it was conducted.

By just considering the success of teachers and schools with only successful and hardworking students, it can be said that other students whose academic level is low or too low are often ignored and are prone and susceptible to any activity that will cause them to fail, direct themselves to violence, to feel alienated and isolated from not only from schools but also the community, refuse the norms and rules imposed on them, have trouble adapting themselves to school setting. They can emerge and appear as unhappy and hopeless adults before us. In order to help them attend school and solve problems thorugh mutual understanding and realistic solutions, fullfill a task that is half-completed, creative drama can play a dramatic role in that it can make contributions to these problems that students with low academic grades experience. In accordance with the results obtained from the study, some proposals can be made:

- More creative drama activities can be held in order to reduce students' alienation level

- This study was done with only K-5 students. The same study can be conducted with other age groups.

- In addition to those who experience alienaton to schools, the same study can be performed with those who experience exhaustion.

- Other factors such as immigration from country to city, content of lessons, attitudes of parents that trigger alienation to schools can be studied in order to reduce alienation.

- By presenting this project as an example to educationists and teachers, the ministry of education can include it as an in-service training class. 